\title{
PENGARUH PEMBERIAN MANURE AYAM PETELUR TERFERMENTASI DALAM PAKAN YANG DITAMBAH ORGANIC DEODORANT TERHADAP PERFORMA ITIK JANTAN UMUR 7-12 MINGGU
}

\section{THE EFFECT OF DIETARY SUPPLEMENTATION OF ORGANIC DEODORANT INCLUSION IN FERMENTED LAYING HENS MANURE ON PERFORMANCE OF 7-12 WEEKS MALE DUCKS}

\author{
Djuriono* \\ SMK Negeri 1 Trucuk, Jurusan Agribisnis Peternakan, Klaten, 57467
}

Submitted: 24 December 2013, Accepted: 2 January 2015

\section{INTISARI}

Penelitian ini bertujuan untuk mengevaluasi pengaruh penggunaan manure ayam petelur terfermentasi yang ditambah organic deodorant (MODF) terhadap performan itik jantan. Seratus ekor itik jantan berumur 7-12 minggu dibagi dalam 5 kelompok perlakuan dengan 4 ulangan, dan setiap ulangan menggunakan 5 ekor itik jantan. Lima macam perlakuan yang digunakan adalah $\mathrm{P} 0=$ pakan komersial tanpa penambahan MODF (ransum kontrol), P15= pakan komersial + 15\% MODF, P30 = pakan komersial $+30 \%$ MODF, P45= pakan komersial + 45\% MODF, P60= level pakan komersial + 60\% MODF. Data yang diperoleh dianalisis menggunakan analisis variansi Rancangan Acak Lengkap pola searah dan dilanjutkan uji Duncan's New Multiple Range Test untuk hasil yang berbeda nyata. Hasil penelitian menunjukkan bahwa substitusi pakan komersial dengan MODF meningkatkan $(P<0,05)$ konsumsi pakan dan FCR, namun menurunkan pertambahan berat badan itik jantan. Konsumsi pakan tertinggi dicapai pada P60 sebesar 5203,50 g, kemudian diikuti oleh P45\%, P30\%, P15\%, dan P0\% masing-masing sebesar 5130,00 g, 5002,75 g, 4967,75 g, 4856,75 g. Pertambahan berat badan tertinggi dicapai oleh P0 $(649,80 \mathrm{~g})$ kemudian diikuti oleh P15 (622,10 g), P30 (579,45 g), P45 (497,50 g), P60 (409,60 g). Rasio konversi pakan tertinggi dicapai oleh P60 (12,71) kemudian diikuti oleh P45 (10,31), P30 (8,64), P15 $(7,99)$, P0 $(7,48)$. Disimpulkan bahwa substitusi MODF pada pakan komersial itik jantan 7-12 minggu tidak menguntungkan, meskipun penambahan MODF $30 \%$ memberikan income over feed cost (IOFC) yang paling tinggi dibandingkan keempat perlakuan yang lain.

(Kata kunci: Fermentasi, Itik jantan, Manure ayam petelur, Organic deodorant, Performa)

\section{ABSTRACT}

The research was conducted to analyze the effect of organic deodorant supplemented fermented laying hens manure feeding on the performance of 7-12 weeks male ducks. One hundred 7 weeks old male ducks were used to study the effetct MODF supplementation on performance of male ducks. The ducks were divided into five groups with four replications consisting of five birds each. The treatment were $P O=$ commercial feed without MODF supplementation (control), $P 15=$ commercial feed $+15 \%$ MODF, $P 30=$ commercial feed $+30 \%$ MODF, P45= commercial feed $+45 \%$ MODF, P60 $=$ commercial feed $+60 \%$ MODF. Data were analyzed with One-Way Classification of Completely Randomized Design and followed by Duncan's New Multiple Range Test (DMRT) for significant results. Results showed that supplementation of fermented MOD gave negative effect $(P<0.05)$ on male ducks performance. The highest consumption was in PO (5203.50 g), followed by P45\% (5130.00 g), P30\% (5002.75 g), P15\% (4967.75 g), P0\% (4856.75 g). The highest weight gain showed in P0 (649.80 g), followed by P15 (622.10 g), P30 (579.45 g), P45 (497.50 g), P60 (409.60 g). The higest feed convertion was in P60 (12.71), followed by P45 (10.31), P30 (8.64), P15 (7.99), P0 (7.48). It could be concluded that it is useless to supplement commercial diet of with MODF even though supplementation of $30 \%$ income over feed cost (IOFC) showed better IOFC of 7-12 weeks male ducks.

(Key words: Fermentated organic deodorant, Laying hens manure, Males ducks, Performance)

\footnotetext{
* Korespondensi (corresponding author):

Telp. +628156702 772

E-mail: djuriono@yahoo.com
} 


\section{Pendahuluan}

Adanya upaya dari pemerintah untuk meningkatkan produksi daging itik telah memberi dorongan bagi kalangan peternak usaha pembesaran itik jantan untuk meningkatkan usahanya. Laju perkembangan peternakan ditentukan oleh tingkat keuntungan yang diraih dan hal ini sangat berkaitan dengan biaya pakan. Upaya penghematan bahan pakan diantaranya menggunakan manure ayam petelur. Populasi ayam ras petelur di Indonesia tahun 2012 sebesar 44.356.543 ekor (Anonim, 2013) dan pada pemeliharaan ayam petelur dapat menghasilkan ekskreta sebesar 52,80 g/ekor/hari (Ensminger, 1982). Produksi manure di Indonesia pada tahun 2012 diperkirakan sebanyak 2.342.025 $\mathrm{kg} / \mathrm{hari}$ (Ensminger, 1982; Anonim, 2013).

Couch (1974) berpendapat bahwa ransum yang dapat dicerna dan dimetabolisir di dalam tubuh berkisar $74 \%$ sehingga manure kering masih mengandung gross energy yang belum tercerna. Wihandoyo et al. (2005) menyatakan bahwa manure ayam mempunyai kandungan protein kasar $29,30 \%$. Potensi manure ini merupakan daya dukung bahan baku yang tersedia secara terus menerus selama populasi ayam petelur tetap stabil atau bahkan ada kecenderungan meningkat sejalan dengan permintaan yang juga meningkat.

Selain itu, permasalahan bau dan keberadaan lalat sering dikeluhkan oleh masyarakat di lingkungan peternakan ayam petelur. Salah satu upaya untuk mengatasi masalah tersebut dengan menggunakan organic deodorant (OD). Djuriono (2012) menyatakan bahwa adanya penambahan OD pada manure ayam petelur dapat mengurangi bau kandang yang tidak sedap dan populasi lalat dapat lebih terkendali. Hasil analisis proksimat OD berupa bahan kering $47,11 \%$, abu $7,83 \%$, protein kasar $2,57 \%$, lemak kasar $0,71 \%$, dan serat kasar $66,59 \%$. Pemberian kapur pada manur kotoran ayam berpengaruh terhadap penurunan kadar air, kenaikan $\mathrm{pH}$, serta penurunan pelepasan gas $\mathrm{H}_{2} \mathrm{~S}$ (Charlena et al., 2006).

Penelitian tentang penggunaan manure ayam petelur dengan penambahan OD pada manure ayam petelur sebagai bahan pakan belum banyak diteliti. Berdasarkan uraian di atas, maka kajian tentang pemanfaatan penambahan OD pada manure ayam petelur terfermentasi sebagai alternatif pengganti pakan komersial pada pemeliharaan itik jantan umur 7-12 minggu dilakukan dalam penelitian ini.

\section{Materi dan metode}

\section{Tempat dan ternak}

Penelitian berlangsung pada bulan September 2012 sampai Februari 2013. Uji pengaruh penggunaan bahan pakan fermentasi manure yang ditambah organic deodorant terhadap performan itik jantan umur 7-12 minggu dilaksanakan di kandang peternakan SMK Negeri 1 Trucuk Klaten. Peralatan yang digunakan antara lain kandang beserta perlengkapan yang berupa tempat pakan, tempat minum, timbangan analitik merk Ohause kapasitas $2610 \mathrm{~g}$ dengan kepekaan 0,01 g, ember, sekop, dan unit-unit pendukung analisis lainnya. Materi penelitian yang digunakan berupa itik jantan umur 7 minggu sebanyak 100 ekor, dibagi dalam 5 kelompok perlakuan, dan diulang 4 kali dengan tiap ulangan menggunakan 5 ekor itik jantan.

\section{Pakan penelitian}

Pakan perlakuan terdiri dari 1) pakan komersial yang terbuat dari konsentrat itik yang ditambahkan jagung dan bekatul, 2) pakan fermentasi manure ayam petelur yang ditambahkan organic deodorant (MODF). Lima macam perlakuan yang digunakan adalah $\mathrm{P} 0=$ pakan komersial $+0 \%$ MODF (kontrol), P15= pakan komersial $+15 \%$ MODF, P30 $=$ pakan komersial $+30 \%$ MODF, $\mathrm{P} 45=$ pakan komersial $+45 \%$ MODF, P60= pakan komersial $+60 \%$ MODF.

\section{Teknik fermentasi manure}

Prosedur pembuatan pakan MODF dimulai dengan mencampur multi microbe 1 $\mathrm{ml}$, $50 \mathrm{ml}$ molasses, $500 \mathrm{ml}$ air dan disiramkan pada $5 \mathrm{~kg}$ bahan (manure tanpa OD dan yang ditambahkan OD) secara merata sehingga kadar air akhir menjadi $35 \%$ (tidak kering dan tidak basah) selanjutnya diinkubasi dalam drum/wadah dalam keadaan tertutup selama 3 hari.

\section{Variabel pengamatan}

Variabel yang diamati yaitu konsumsi pakan, pertambahan berat badan, konversi pakan, dan income over feed cost (IOFC). Konsumsi pakan (g/ekor/hari) dihitung berdasarkan jumlah pakan yang diberikan dikurangi sisa pakan pada hari ke-35. 
Pertambahan berat badan selama 5 minggu diperoleh dengan menghitung selisih bobot badan hari ke-35 dengan bobot badan awal dinyatakan dalam g/ekor. Konversi pakan (feed conversion ratio) dihitung berdasarkan perbandingan antara konsumsi ransum dengan pertambahan berat badan. Perhitungan IOFC berdasarkan harga pakan yang dikeluarkan untuk produksi/pertambahan bobot itik selama penelitian dengan rumus IOFC $=(B B \times$ harga itik $/ \mathrm{kg}$ hidup) - (jumlah konsumsi pakan $\mathrm{x}$ biaya pakan/kg).

\section{Analisis data}

Data dianalisis menggunakan analisis One Way Anova. Perbedaan yang signifikan antar perlakuan diuji lanjut dengan Duncan's New Multiple Range Test (Astuti, 2007).

\section{Hasil dan Pembahasan}

\section{Konsumsi pakan}

Pengaruh level penggunaan bahan pakan manure fermentasi yang ditambah organic deodorant terhadap konsumsi pakan itik jantan selama penelitian disajikan pada Tabel 2. Hasil analisis statistik menunjukkan bahwa penambahan MODF dalam pakan komersial meningkatkan konsumsi pakan $(P<0,05)$. Konsumsi pakan itik jantan tertinggi dicapai oleh pakan kontrol (100\% pakan komersial) sebesar 5203,50 g, kemudian diikuti oleh pakan dengan level substitusi MODF 45\%, MODF 30\%, MODF 15\%, MODF 0\% masing-masing sebesar 5130,00 $\mathrm{g}, 5002,75 \mathrm{~g}, 4967,75 \mathrm{~g}$, dan 4856,75 g.

Hasil penelitian menunjukkan bahwa semakin tinggi substitusi MODF dalam ransum meningkatkan konsumsi pakan yang berarti konsumsi pakan naik seiring dengan bertambahnya MODF di dalam ransum.
Meningkatnya konsumsi pakan ini diduga karena kandungan energi yang terdapat dalam ransum turun seiring dengan bertambahnya subtsitusi MODF. Jumlah ransum yang dikonsumsi ditentukan oleh tingkat energi yang ada di dalam pakan (Scott et al., 1982).

Konsumsi pakan akan meningkat apabila diberi pakan dengan kandungan energi rendah dan akan turun apabila kandungan energi dalam ransum tinggi (Anggorodi, 1994). Semua faktor yang berhubungan dengan adanya peningkatan atau penurunan kebutuhan energi sangat mempengaruhi regulasi nafsu makan pada ternak unggas (Zuprizal, 2006).

Data pada Tabel 2 menunjukkan adanya peningkatan kandungan serat kasar dalam ransum seiring dengan kenaikan tingkat substitusi MODF. Semakin tinggi kandungan serat kasar dalam ransum meningkatkan konsumsi pakan. Farrell (1979) menyatakan bahwa pakan yang masuk ke dalam saluran pencernaan akan dilewatkan lebih cepat pada ransum yang mengandung serat kasar tinggi karena konsumsi air minum yang tinggi.

Konsumsi pakan semakin meningkat seiring dengan umur itik dan terjadi pada semua perlakuan P0, P15, P30, P45, dan P60. Hal ini menunjukkan substitusi pakan MODF secara bertingkat sampai pada level $60 \%$ berpengaruh terhadap nafsu makan itik dan banyaknya pakan yang dikonsumsi meningkat dengan umur itik. Anggorodi (1994) menyatakan bahwa jumlah konsumsi pakan tergantung dari kebutuhan hewan yang bersangkutan dan tergantung dari ukuran, keaktifan, suhu lingkungan, dan untuk pertumbuhan atau untuk mempertahankan produksi.

Tabel 1. Kandungan nutrien pakan percobaan MODF (nutrient contents of experimental diets MODF)

\begin{tabular}{|c|c|c|c|c|c|c|c|}
\hline $\begin{array}{l}\text { Perlakuan } \\
\text { (treatment) }\end{array}$ & $\begin{array}{c}\text { BK (\%) } \\
(D M(\%))\end{array}$ & $\begin{array}{l}\text { Abu (\%) } \\
\text { (ash (\%)) }\end{array}$ & $\begin{array}{l}\text { PK (\%) } \\
(C P(\%))\end{array}$ & $\begin{array}{l}\text { LK (\%) } \\
(E E(\%))\end{array}$ & $\begin{array}{l}\text { SK (\%) } \\
(C F(\%))\end{array}$ & $\begin{array}{l}\text { BETN (\%) } \\
(N F E(\%))\end{array}$ & $\begin{array}{c}\text { Metabolism } \\
\text { energy }(\mathrm{kcal} / \mathrm{kg})\end{array}$ \\
\hline P0 & 91,74 & 15,85 & 15,47 & 3,36 & 8,37 & 56,66 & 2744,69 \\
\hline P15 & 90,90 & 17,34 & 14,48 & 3,62 & 9,17 & 55,75 & 2627,08 \\
\hline P30 & 91,25 & 20,30 & 14,18 & 2,85 & 9,20 & 53,47 & 2461,76 \\
\hline P45 & 92,08 & 23,47 & 13,32 & 2,42 & 9,81 & 50,98 & 2254,93 \\
\hline P60 & 92,48 & 25,63 & 13,05 & 2,65 & 10,51 & 48,16 & 2117,22 \\
\hline
\end{tabular}

P0: pakan komersial + 0\% MODF (commercial feed without MODF supplementation), P15: pakan komersial + 15\% MODF (commercial feed + 15\% MODF), P30: pakan komersial + 30\% MODF (commercial feed + 30\% MODF), P45: pakan komersial $+45 \%$ MODF (commercial feed $+45 \%$ MODF), P60: pakan komersial + 60\% MODF (commercial feed $+60 \%$ MODF).

BK: bahan kering (DM: dry matter), PK: protein kasar (CP: crude protein), LK: lemak kasar (EE: extract ether), SK: serat kasar (CF: crude fibre), BETN: bahan ekstrak tanpa nitrogen (nitrogen free extract). 


\section{Pertambahan bobot badan}

Pengaruh penggunaan manure terfermentasi yang ditambah organic deodorant terhadap pertambahan bobot badan itik jantan disajikan pada Tabel 2. Hasil analisis statistik menunjukkan bahwa penambahan MODF dalam ransum menurunkan pertambahan bobot badan itik $(P<0,05)$. Pertambahan bobot badan itik jantan tertinggi dicapai pada P0 $(649,80 \mathrm{~g})$ kemudian diikuti P15 (622,10 g), P30 (579,45 g), P45 (497,50 g), P60 (409,60 g). Hal ini memperlihatkan bahwa pertambahan bobot badan turun seiring dengan bertambahnya tingkat substitusi MODF dalam ransum.

Perbedaan pertambahan bobot badan ini diduga karena kandungan nutrien terutama kadar protein yang terdapat di dalam ransum semakin turun seiring dengan naiknya substitusi MODF. Adanya pertambahan bobot hidup merupakan refleksi dari jumlah protein yang dikonsumsi. Kandungan protein pada substitusi MODF perlakuan P15 lebih tinggi dibanding dengan perlakuan lainnya, sehingga memberikan PBB yang tinggi. Protein diperlukan untuk mengganti jaringan yang rusak, komponen enzim, hormon, dan antibodi (Anggorodi, 1994).

Pertambahan bobot badan pada pakan komersial dengan penggantian pakan MODF $60 \%$ (P60) paling rendah yaitu sebesar 409,60 g/ekor. Hal ini diduga karena P60 memiliki level serat kasar paling tinggi dibandingkan perlakuan lainnya. Level serat kasar yang tinggi dalam ransum sering menyebabkan kecernaan turun (Khuzaemah, 2005) dan pemanfaatan nutrien ransum menjadi turun serta penurunan bobot badan (Hsu et al., 2000). Anggorodi (1994) menyatakan bahwa kesanggupan ternak dalam mencerna serat kasar tergantung dari jenis alat pencernaan yang dimiliki oleh ternak tersebut dan tergantung pula dari mikroorganisme yang terdapat dalam alat pencernaan.

Perlakuan tingkat substitusi MODF $60 \%$ menunjukkan masih adanya pertambahan bobot pada itik jantan meskipun paling ringan dibandingkan dengan perlakuan yang lain, hal ini mengindikasikan bahwa nutrien yang terkandung di dalam pakan masih dapat dimanfaatkan secara optimal oleh itik jantan. Wihandoyo et al. (2005) menyatakan bahwa ekskreta ayam mem-punyai kandungan protein kasar 29,30\%. Couch (1974) berpendapat bahwa ransum yang dapat dicerna dan dimetabolisme di dalam tubuh berkisar $74 \%$ sehingga manure kering masih mengandung gross energy yang belum tercerna.

Adanya pertambahan bobot badan mengindikasikan adanya pertumbuhan pada itik jatan. Ensminger (1982) menyatakan bahwa pertumbuhan didefinisikan sebagai kenaikan bobot badan yang diikuti dengan pertambahan besar dari urat daging, ukuran tulang, organ-organ dalam dan bagian tubuh lainnya. Pertambahan bobot badan merupakan bagian dari pertumbuhan. Tillman (1998) menyatakan bahwa fungsi makanan untuk proses pertumbuhan, produksi, reproduksi, dan pemeliharaan tubuh. Pertambahan bobot badan juga mengindikasikan terjadinya penambahan tenunan otot pada tubuh itik yang berarti nilai retensi nitrogennya positif. Nilai retensi nitrogen yang tinggi dapat memberikan manfaat yang lebih besar bagi ternak (Anggorodi, 1994).

Penambahan MODF dalam pakan menurunkan pertambahan bobot badan. Hal ini diduga disebabkan karena nutrisi esensial

Tabel 2. Rerata konsumsi pakan, pertambahan bobot badan, dan konversi pakan pada itik jantan dengan pakan yang disubstitusi MODF (average of feed consumption, body weight gain and feed convertion of male duck fed of MODF substitute diet)

\begin{tabular}{|c|c|c|c|c|c|}
\hline \multirow[t]{2}{*}{ Variabel (variable) } & \multicolumn{5}{|c|}{ Perlakuan (treatment) } \\
\hline & $\mathrm{PO}$ & P15 & P30 & P45 & P60 \\
\hline $\begin{array}{l}\text { Konsumsi pakan } \\
\text { (feed intakes) }\end{array}$ & $4856,75 \pm 40,49^{a}$ & $4967,75 \pm 35,11^{b}$ & $5002,75 \pm 13,38^{b}$ & $5130,00 \pm 16,15^{c}$ & $5203,50 \pm 5,07^{d}$ \\
\hline PBB & $649,80 \pm 18,25^{\mathrm{e}}$ & $622,10 \pm 11,11^{d}$ & $579,45 \pm 20,97^{c}$ & $497,50 \pm 4,58^{b}$ & $409,60 \pm 5,35^{a}$ \\
\hline $\begin{array}{l}\text { Konversi pakan } \\
\text { (feed conversion) }\end{array}$ & $7,48 \pm 0,53^{a}$ & $7,99 \pm 0,68^{b}$ & $8,64 \pm 0,71^{\mathrm{c}}$ & $10,31 \pm 0,53^{d}$ & $12,71 \pm 0,53^{\mathrm{e}}$ \\
\hline
\end{tabular}

PBB: pertambahan bobot badan (body weight gain),

P0: pakan komersial + 0\% MODF (commercial feed without MODF supplementation), P15: pakan komersial + 15\% MODF (commercial feed + 15\% MODF), P30: pakan komersial + 30\% MODF (commercial feed + 30\% MODF), P45: pakan komersial + 45\% MODF (commercial feed + 45\% MODF), P60: pakan komersial + 60\% MODF (commercial feed $+60 \%$ MODF).

a,b,c,d,e Superskrip yang berbeda pada kolom yang sama menunjukkan perbedaan yang nyata $(P<0,05)($ different superscripts at the same column indicate significant differences $(P<0.05))$. 
yang terkandung di dalam pakan makin rendah. Scott et al. (1982) menyatakan bahwa nutrisi esensial harus ada dalam makanan dengan jumlah yang cukup untuk meningkatkan rerata pertumbuhan, produksi telur yang optimum dan meningkatkan reproduksi dengan maksimum efisiensi penggunaan pakan. Dengan demikian, level substitusi $15-30 \%$ MODF dalam ransum dapat ditolerir itik jantan umur 17 minggu karena pada level tersebut itik jantan mampu memanfaatkan nutrien secara efisien.

\section{Konversi pakan}

Pengaruh penggunaan bahan pakan fermentasi manure yang ditambah organic deodorant terhadap konversi pakan itik jantan selama penelitian disajikan pada Tabel 2. Hasil analisis statistik menunjukkan bahwa penambahan MODF dalam pakan menaikkan konversi pakan $(P<0,05)$. Konversi pakan itik jantan tertinggi dicapai oleh P60 dengan rerata 12,71 kemudian diikuti oleh P45 (10,31), P30 (8,64), P15 $(7,99)$, dan P0 $(7,48)$. Adanya peningkatan level substitusi pakan MODF mengakibatkan konversi pakan bertambah besar sehingga tingkat efisiensi pakan makin berkurang. Anggorodi (1994) menyatakan bahwa semakin tinggi nilai konversi pakan maka semakin rendah tingkat efisiensi penggunaan pakan. Tingginya konversi pakan dengan substitusi MODF sangat berkaitan dengan kualitas pakan yang semakin rendah seiring dengan penambahan substitusi pakan komersial. Faktor yang mempengaruhi besar kecilnya konversi pakan meliputi daya cerna ternak, kualitas pakan yang dikonsumsi serta keserasian nilai nutrien yang dikandung pakan tersebut. Ketaren et al. (2002) berpendapat bahwa tingginya FCR pada pemeliharaan itik dapat disebabkan oleh tiga faktor utama yaitu (1) mutu genetik (2) banyak pakan tercecer dan (3) kandungan gizi pakan yang diberikan tidak sesuai dengan yang dibutuhkan. Nilai FCR yang tinggi menyebabkan melonjaknya biaya pakan yang harus dikeluarkan, karena kenaikan nilai FCR berhubungan erat dengan harga pakan. Kenaikan FCR dapat menurunkan bahkan menghilangkan keuntungan peternak (Hasan, 2012).

\section{Income over feed cost}

Perhitungan terhadap pemasukan dan pengeluaran biaya menghasilkan nilai pendapatan di luar biaya pakan (income over feed cost/IOFC) selama pemeliharaan itik. Harga pakan komersial yang terdiri dari konsentrat, jagung dan bekatul pada saat penelitian dihitung sebesar Rp6.300,00/kg, Rp3.500,00/kg dan Rp2.500,00/kg. Pada formula pakan komersial yang terdiri dari konsentrat $19,2 \%$, jagung $28,5 \%$, bekatul $52,3 \%$ diperoleh harga Rp3.515,00 per $\mathrm{kg}$ dan pakan substitusi MODF yang terdiri dari P15, P30, P45, P60 masing-masing dengan harga Rp3.137,00 per kg, Rp2.759,00 per kg, Rp2.381,00 per kg, Rp2.003,00 per kg. Perhitungan pemasukan berupa pertambahan bobot badan disetarakan dengan penjualan itik hidup sebesar Rp25.00,00 per kg. Pengaruh penggunaan bahan pakan fermentasi manure yang ditambahkan organic deodorant terhadap IOFC disajikan pada Tabel 3.

Berdasarkan Tabel 3 disimpulkan bahwa tingkat substitusi bahan pakan MODF $30 \%$ (P30) diperoleh IOFC yang paling tinggi dalam pembesaran itik jantan. Hal ini disebabkan karena penggunaan pakan P30 lebih murah jika dibanding P0 dan P15 diikuti dengan performan itik yang hampir sebanding.

Tabel 3. Analisis IOFC pada pemeliharaan itik jantan dengan pakan yang disubstitusi MODF (analyzing of income over feed cost of male duck rearing fed MODF substitute diet)

\begin{tabular}{|c|c|c|c|}
\hline $\begin{array}{l}\text { Perlakuan } \\
\text { (treatment) }\end{array}$ & Biaya pakan (feed cost) & Pemasukan (income) & $\begin{array}{c}\text { Income over feed } \\
\text { cost (Rp) (IOFC }(R p))\end{array}$ \\
\hline P0 & 17069,53 & 16245,00 & $-824,53$ \\
\hline P15 & 15581,73 & 15552,50 & $-29,23$ \\
\hline P30 & 13800,35 & 14486,25 & 685,89 \\
\hline P45 & 12212,12 & 12437,50 & 225,38 \\
\hline P60 & 10420,04 & 10240,00 & $-180,04$ \\
\hline
\end{tabular}


Rendahnya nilai keuntungan sebesar Rp685,89,00 per ekor pada P30 disebabkan karena income yang berasal dari pertambahan bobot badan sangat rendah dan harga bahan pakan terutama konsentrat, jagung, dan katul yang cukup tinggi. Naiknya sarana produksi menyebabkan peningkatan biaya produksi tetapi menurunkan pendapatan peternak sampai di bawah ambang batas titik impas. Pakan merupakan salah satu faktor strategis yang dapat mempengaruhi produksi dan produktivitas ternak, disamping itu biaya untuk pakan menempati porsi terbesar dari total biaya produksi yaitu $70-80 \%$, sehingga memproduksi pakan tidak hanya harus berkualitas tetapi juga dengan harga yang terjangkau oleh para peternak unggas (Anonim, 2012).

Peternak itik jantan pada saat ini banyak yang usahanya rugi karena faktor biaya pakan tinggi yang diikuti harga jual itik hidup rendah. Turunnya pendapatan peternak yang berkepanjangan menyebabkan peternak menghentikan usahanya (Hasan, 2012). Penggunaan substitusi MODF sebagai bahan pakan alternatif dapat dijadikan salah satu strategi dalam usaha pembesaran itik jantan agar tetap berkesinambungan. Potensi bahan pakan pada setiap daerah baik yang berasal dari hasil pertanian maupun agroindustri dapat dimanfaatkan untuk menyusun formula pakan unggas lokal dengan harga yang lebih murah dan memenuhi kecukupan gizi, sehingga dapat meningkatkan keuntungan peternak (Anonim, 2012).

\section{Kesimpulan}

Hasil penelitian menunjukkan bahwa penambahan MODF sebaiknya tidak dilakukan karena menaikkan konsumsi pakan dan menurunkan pertambahan bobot badan, sehingga berakibat pada naiknya nilai konversi pakan.

\section{Ucapan Terima Kasih}

Naskah ini banyak mendapatkan masukan dari Prof. Ali Agus dan Dr. Subur Priyono Sasmito Budhi, untuk itu penulis menyampaikan terima kasih yang sebesarbesarnya.

\section{Daftar Pustaka}

Anggorodi. 1994. Ilmu Makanan Ternak Umum. PT. Gramedia Pustaka Utama, Jakarta.

Anonim. 2012. Pedoman Umum Pengembangan Lumbung Pakan Unggas. Direktorat Jenderal Peternakan dan Kesehatan Hewan Kementrian Pertanian, Jakarta.

Anonim. 2013. Data Lima Tahun Subsektor Peternakan. http://www.deptan.go.id/ infoeksekutif/nak/isi_dt5thn_nak.php. Diakses pada 17 September 2013.

Astuti, J. M. 2007. Pengantar IImu Statistik untuk Peternakan dan Kesehatan Hewan. Binasti Publisher, Bogor.

Charlena, I., H. Suparto, dan A. E. Praja. 2006. Pengaruh kapur terhadap pelepasan gas $\mathrm{H}_{2} \mathrm{~S}$ dan unsur hara pada manur ayam petelur. Prosiding Fakultas Matematika dan IImu Pengetahuan Alam, Institut Pertanian Bogor, Bogor.

Couch, J. R. 1974. Evaluation of poultry manure as a feed ingredient. World's Poult. Sci. J. 30: 279-289.

Djuriono. 2012. Bau-Go produk pengendali bau sampah dan kotoran ternak yang ramah lingkungan. Laporan Penelitian SMK Negeri 1 Trucuk, Klaten.

Ensminger, M. E. 1982. Poultry Science. Animal Agriculture Series. $2^{\text {nd }}$ edn. The Interstate Printers and Publisher Inc. Danville.

Farrell, D. 1979. Pengaruh dari suhu tinggi terhadap kemampuan biologis unggas. Seminar IImu dan Industri Perunggasan II, Pusat Penelitian dan Pengembangan Ternak, Bogor.

Hsu, J. C., L. I. Chen and B. Yu. 2000. Effect of levels of crude fiber on growth performances and intestinal carbohydrase of domestic gosling. Asian-Aust. J. Anim. Sci. 10: 14501455.

Ketaren, P. P. dan L. H. Prasetyo. 2002. Pengaruh Pemberian Pakan Terbatas terhadap Produktivitas Itik Silang Mojosari X Alabio (Ma): 1. Masa Bertelur Fase Pertama Umur 20-43 Minggu. Balai Penelitian Ternak, Bogor. 
Khuzaemah, S. 2005. Pengaruh aras serat kasar ransum terhadap kecernaan serat kasar, protein kasar dan energi metabolis pada itik Tegal jantan. Skripsi Fakultas Peternakan, Universitas Diponegoro, Semarang.

Scott, M. L., M. C. Nesheim and R. J. Young, 1982. Nutrition of Chicken. $3^{\text {rd }}$ edn. M. L. Scott and Associates, Ithaca, New York.

Hasan, S., Suryahadi, dan A. Saleh. 2012. Analisis kelayakan usaha peternakan ayam pedaging dengan pola kemitraan di Kecamatan Ciampea Kabupaten Bogor. http://journal.ipb.ac.id/index. php./jurnalmpi/. Diakses pada 17 September 2013.
Tillman, A. D., H. Hartadi, S. Reksohadiprodjo, S. Prawirokusumo, dan S. Lebdosoekojo. 1998. IImu Makanan Ternak Dasar. Gadjah Mada Press, Yogyakarta.

Wihandoyo, A. R. Alimon and H. Kassim. 2005. Control of amonia emission and house fly population in poultry house: 2. Effect of dietary zeolite and direct aplication to chicken manure. Malaysian J. Anim. Sci. 10: 82-89.

Zuprizal. 2006. Nutrisi Unggas. Jurusan Nutrisi dan Makanan Ternak, Fakultas Peternakan, Universitas Gadjah Mada, Yogyakarta. 